\title{
Perspektif Riba dan Studi Kontemporer-Nya dengan Pendekatan Tafsir Al Quran dan Hadits ${ }^{1}$
}

\author{
Salman Al Parisi ${ }^{1}$, Iwan Hermawan ${ }^{2}$, Marta Kurniawan ${ }^{3}$ dan Ibnu Saud Habibullah ${ }^{4}$ \\ ${ }^{1}$ Mahasiswa Pascasarjana SB IPB EK 24 E Awardee LPDP PK 103, Asisten Peneliti Bank Indonesia, \\ salman_alparisi@apps.ipb.ac.id. \\ ${ }^{2}$ Mahasiswa Pascasarjana SB IPB EK 24, Ajun Ahli Asuransi Kerugian PT Jasindo, Jakarta, \\ iwan_hermawan@apps.ipb.ac.id \\ ${ }^{3}$ Mahasiswa Pascasarjana SB IPB EK 24, Pejabat pengawas Kementerian BUMN - Jakarta, \\ marta_kurniawan@apps.ipb.ac.id \\ ${ }^{4}$ Mahasiswa Pascasarjana SB IPB EK 24, ibnu_saud@apps.ipb.ac.id
}

\begin{abstract}
This paper addresses the urgency and stages of prohibition of riba in Islamic perspective. This study uses a study of theory related to riba with the Quran and Hadith interpretation approach. In general, riba consists of two groups which are riba based on borrowing transactions (riba qardh and riba jahiliyyah) and riba based on selling and purchasing of ribaval goods (riba fadhl and riba nasi'ah). Based on the Quran, the stages of the prohibition of riba consist of 4 stages, begin with Q.S. Ar-Ruum: 39, Q.S. An-Nisa: 160-161, Q.S. Ali Imran: 130 and the last stage of Q.S. Al-Baqarah: 275-281. As for one of the related hadith narrated by Al-Hakim from Ibn Mas'ud that Prophet Muhammad PBUH said "Riba has 73 doors (levels); the lowest (of sin) is the same as someone who commits adultery with his mother ". So there is no justification in taking riba, as the Prophet emphasized in his last mandate on 9 Dzulhijjah in 10 Hijriah, "Remember that you will come to your God and He will surely count your doing."
\end{abstract}

Keywords: Riba, Prohibition of Riba in the Quran and Hadith, Contemporary Studies

\begin{abstract}
Abstrak
Paper ini membahas urgensi dan tahapan pelarangan riba dalam perspektif Islam. Studi ini menggunakan kajian pustaka terkait riba dengan pendekatan tafsir Quran dan Hadits. Secara umum, riba terdiri atas 2 kelompok bagian yaitu riba berdasarkan transaksi hutang piutang (riba qardh dan riba jahiliyyah) serta riba berdasarkan transaksi jual beli barang ribawi (riba fadhl dan riba nasi'ah). Berdasarkan Al- Quran, tahapan larangan riba terdiri atas 4 tahap, yaitu Q.S. Ar-Ruum: 39, Q.S. AnNisa: 160-161, Q.S. Ali Imran: 130 dan tahap terakhir Q.S. Al-Baqarah: 275-281. Adapun salah satu hadits terkait riba yang diriwayatkan oleh Al-Hakim dari Ibnu Mas'ud bahwa Nabi saw bersabda "Riba itu mempunyai 73 pintu (tingkatan); yang paling rendah (dosanya) sama dengan seseorang yang melakukan zina dengan ibunya". Maka tidak ada pembenaran dalam mengambil riba, sebagaimana Rasulullah saw menekankan dalam amanat terakhirnya pada tanggal 9 Dzulhijjah tahun 10 Hijriah, “Ingatlah bahwa kamu akan menghadap Tuhanmu dan Dia pasti akan menghitung amalanmu.
\end{abstract}

Kata Kunci: Riba, Larangan Riba Dalam Al-Quran dan Hadits, Studi Kontemporer

\footnotetext{
${ }^{1}$ Paper ini adalah sebagai tugas mata kuliah Bahasa Arab (Tafsir Hadits Ekonomi dan Manajemen) yang diampuh oleh Prof. Dr. Ir. KH. Didin Hafidhuddin, MSc dan Dr. Irfan Syauqi Beik, SP, M.Si.
} 


\section{PENDAHULUAN}

\section{Latar Belakang}

Syariah Islam memiliki keunikan tersendiri, yang tidak hanya bersifat komprehensif tetapi juga universal (Antonio, 2001:4). Seluruh aspek dalam kehidupan ini termasuk kegiatan muammalah (ekonomi dan sosial) diatur oleh Islam untuk mencapai kemashlahatan dan kesejahteraan bagi manusia. Dalam menjalani kehidupan, manusia harus bekerja keras, ikhtiyar dan berdoa.

Dalam Islam ada suatu kaidah yang dikenal sebagai kaidah fiqih, salah satu kaidah yang berbunyi al ashlu fi al mua'malah al ibahah illa ma dalla dalil ala tahrimiha yang artinya pada hakikatnya dalam mua'malah segala sesuatu diperbolehkan untuk dilakukan selama tidak ada dalil yang mengharamkannya. Dari kaidah tersebut manusia boleh melakukan aktivitas usaha yang tidak bertentangan dengan hukum Islam agar selamat baik dunia maupun akhirat seperti jual beli (perdagangan barang maupun jasa), sewa, bagi hasil proyek dan lainnya.

Jual beli merupakan kegiatan usaha yang positif dan dihalalkan oleh- Nya. Sudah sangat jelas bahwa jual beli dihalalkan dan riba hukumnya haram (Q.S. Al-Baqarah: 275), jadi antara keduanya tidak dapat dipersamakan. Akan tetapi mayoritas manusia masih belum sadar, pelaku hanya ingin mendapat keuntungan tanpa usaha yang keras dalam waktu yang singkat. Anggapan pelaku bahwa hal yang terpenting yaitu dapat hidup penuh dengan harta, kekayaan dan martabat duniawi. Pada hakikatnya, mereka dalam keadaan yang rugi dan sesat. Orang yang memakan riba tidak dapat berdiri ${ }^{2}$ melainkan seperti orang yang kerasukan setan lantaran penyakit gila yang diakibatkan kehampaan spritual dalamjiwa dan dirinya yang jauh akan Tuhannya (Q.S. Al- Baqarah: 275).

Riba secara etimologi bermakna ziyadah (يادة - tambahan), dan menurut Leiden (1996) riba juga berarti tumbuh dan membesar. Secara terminologi, riba berarti pengambilan tambahan harta pokok atau modal secara bathil atau tanpa adanya satu transaksi pengganti

\footnotetext{
${ }^{2}$ Dalam kitab tafsir fi zhilalil qur'an yang dimaksud dengan 'berdiri' dalam gambaran yang menakutkan ini adalah berdiri pada hari kiamat ketika dibangkitkan dari kubur (Quthb, 2000:380)
}

atau penyeimbang baik dalam transaksi jual beli maupun pinjam meminjam secara bathil atau bertentangan dengan prinsip muammalah dalam Islam (Antonio, 2001:37).

Riba merupakan hal yang urgen untuk dikaji sebab aktivitas ekonomi dan sosial masyarakat cenderung rentan dari aplikasi riba. Sedangkan riba menjadi salah satu sebab disparitas pendapatan menjadi semakin lebar antar golongan masyarakat. Jabir berkata bahwa Rasulullah saw. mengutuk orang yang menerima riba, orang yang membayarnya, dan orang yang mencatatnya, dan dua orang saksinya, kemudian beliau bersabda, "Mereka itu semuanya sama." (H.R. Muslim) ${ }^{3}$. Sehingga paper ini bertujuan untuk membahas urgensi larangan riba berdasarkan AlQuran dan Hadits serta studi kasus kontemporer terkait praktik riba saat ini.

\section{PEMBAHASAN}

\section{Jenis- Jenis Riba}

Secara garis besar, riba dikelompokkan menjadi dua bagian yaitu riba utang-piutang dan riba jual beli. Kelompok pertama terbagi menjadi riba qardh dan riba jahiliyyah. Sedangkan riba jual beli terbagi menjadi riba fadhl dan riba nasi'ah (Antonio, 2001:41).

1. Riba Qardh yaitu suatu manfaat atau tingkat kelebihan tertentu yang disyaratkan terhadap yang berutang.

2. Riba Jahiliyyah yaitu utang dibayar lebih dari pokoknya karena si peminjam tidak mampu membayar utangnya pada waktu yang ditetapkan.

3. Riba Fadhl yaitu pertukaran antar barang sejenis dengan kadar atau takaran yang berbeda, sedangkan barang yang dipertukarkan itu termasuk dalam jenis barang ribawi.

4. Riba Nasi'ah yaitu penangguhan penyerahan atau penerimaan jenis barang ribawi yang dipertukarkan dengan jenis barang ribawi lainnya. Riba dalam nasi'ah muncul karena adanya perbedaan, perubahan, atau tambahan antara yang diserahkan saat ini dan yang diserahkan kemudian.

\footnotetext{
${ }^{3}$ H.R. Muslim No. 2995, Kitab Al-Masaqqah.
} 
Adapun jenis barang ribawi meliputi; 1) emas dan perak baik itu dalam bentuk uang maupun dalam bentuk lainnya, dan 2) bahan makanan pokok, seperti beras, gandum, dan jagung serta bahan makanan tambahan, seperti sayur-sayuran dan buah- buahan.

\section{Ayat dan Hadits Tentang Riba}

Tahap pertama, Q.S. Ar-Ruum ayat 39

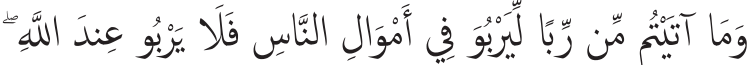

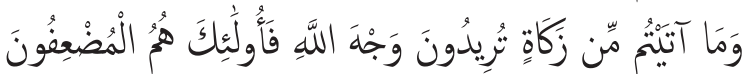

$[q \mu: \cdot r]$

"Dan sesuatu riba (tambahan) yang kamu berikan agar dia bertambah pada harta manusia, maka riba itu tidak menambah pada sisi Allah. Dan apa yang kamu berikan berupa zakat yang kamu maksudkan untuk mencapai keridhaan Allah, maka (yang berbuat demikian) itulah orang-orang yang melipat gandakan (pahalanya)" (Q.S. Ar-Ruum: 39).

\section{Tahap kedua, Q.S. An- Nisa ayat 160-161}

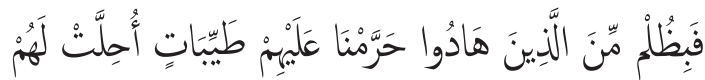

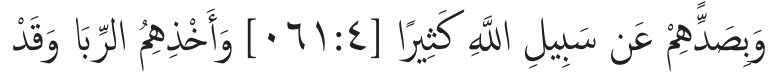

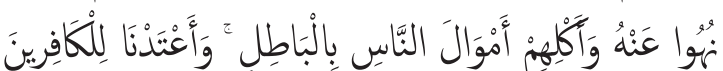

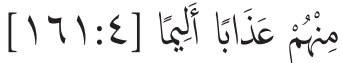

"Maka disebabkan kezaliman orang-orang Yahudi, kami haramkan atas (memakan makanan) yang baik-baik (yang dahulunya) dihalalkan bagi mereka, dan karena mereka banyak menghalangi (manusia) dari jalan Allah, dan disebabkan mereka memakan riba, padahal sesungguhnya mereka telah dilarang daripadanya, dan karena mereka memakan harta benda orang dengan jalan yang batil. Kami telah menyediakan untuk orang-orang yang kafir di antara mereka itu siksa yang pedih" (Q.S. AnNisa: 160-161).

\section{Tahap ketiga, Q.S. Ali Imron ayat 130}

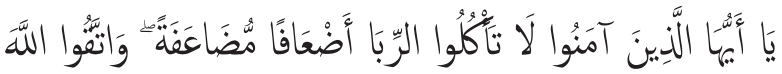

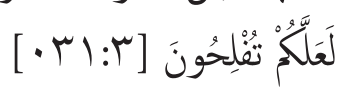

"Hai orang-orang yang beriman, janganlah kamu memakan riba dengan berlipat ganda] dan bertakwalah kamu kepada Allah supaya kamu mendapat keberuntungan" (Q.S. Ali Imron: 130).

\section{Tahap keempat, Q.S. Al-Baqarah ayat 275 -} 281

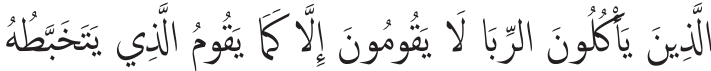

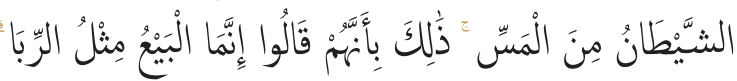

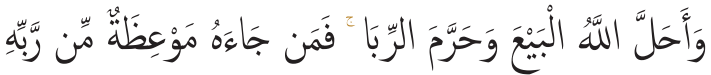

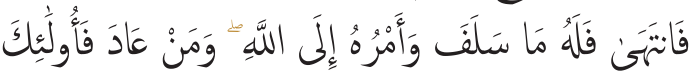

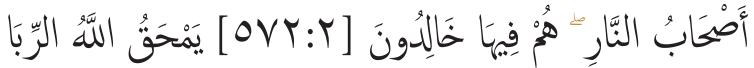

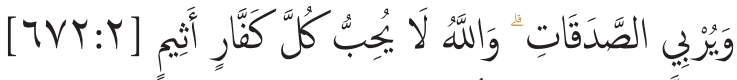

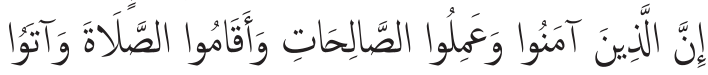

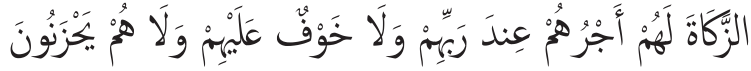

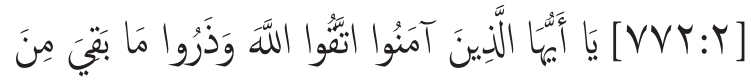

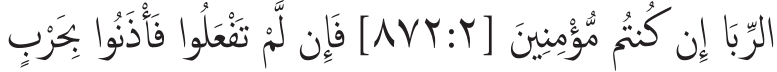

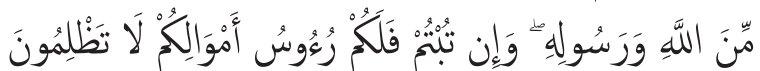

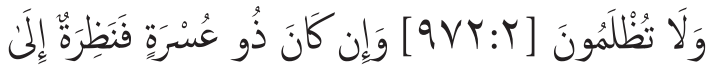

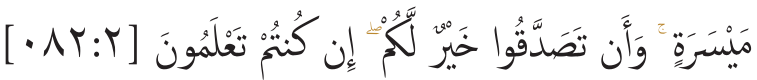

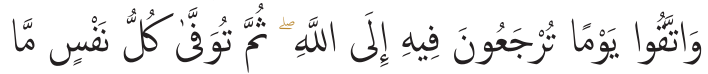

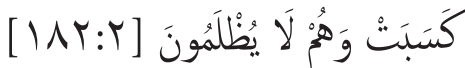

"Orang-orang yang makan (mengambil) riba tidak dapat berdiri melainkan seperti berdirinya orang yang kemasukan syaitan lantaran (tekanan) penyakit gila. Keadaan mereka yang demikian itu, adalah disebabkan mereka berkata (berpendapat), sesungguhnya jual beli itu sama dengan riba, padahal Allah telah menghalalkan jual beli dan mengharamkan riba. Orang-orang yang telah sampai kepadanya larangan dari Tuhannya, lalu terus berhenti (dari mengambil riba), maka baginya apa yang telah diambilnya dahulu (sebelum datang larangan); dan urusannya (terserah) kepada Allah. Orang yang kembali (mengambil riba), maka orang itu adalah penghuni-penghuni neraka; mereka kekal di dalamnya (Q.S. 2:275). Allah memusnahkan riba dan menyuburkan sedekah. Dan Allah tidak menyukai setiap orang yang tetap dalam kekafiran, dan selalu berbuat dosa (Q.S. 2:276). Sesungguhnya 
orang-orang yang beriman, mengerjakan amal saleh, mendirikan shalat dan menunaikan zakat, mereka mendapat pahala di sisi Tuhannya. Tidak ada kekhawatiran terhadap mereka dan tidak (pula) mereka bersedih hati (Q.S. 2:277). Hai orang-orang yang beriman, bertakwalah kepada Allah dan tinggalkan sisa riba (yang belum dipungut) jika kamu orang-orang yang beriman (Q.S. 2:278). Maka jika kamu tidak mengerjakan (meninggalkan sisa riba), maka ketahuilah, bahwa Allah dan Rasul-Nya akan memerangimu. Dan jika kamu bertaubat (dari pengambilan riba), maka bagimu pokok hartamu; kamu tidak menganiaya dan tidak (pula) dianiaya" (Q.S. 2:279). Dan jika (orang yang berhutang itu) dalam kesukaran, maka berilah tangguh sampai dia berkelapangan. Dan menyedekahkan (sebagian atau semua utang) itu, lebih baik bagimu, jika kamu mengetahui (Q.S. 2:280). Dan peliharalah dirimu dari (azab yang terjadi pada) hari yang pada waktu itu kamu semua dikembalikan kepada Allah. Kemudian masing-masing diri diberi balasan yang sempurna terhadap apa yang telah dikerjakannya, sedang mereka sedikitpun tidak dianiaya (dirugikan) (Q.S. 2:281).

\section{Hadits- Hadits Tentang Riba}

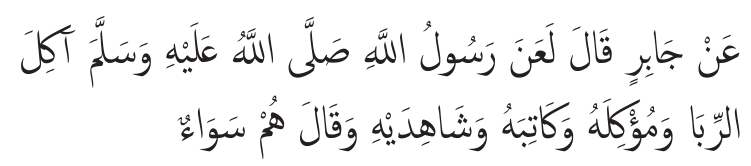

Dari Jabir dia berkata, "Rasulullah shallallahu 'alaihi wasallam melaknat pemakan riba, orang yang menyuruh makan riba, juru tulisnya dan saksi-saksinya." Dia berkata, "Mereka semua sama." (HR. Muslim).

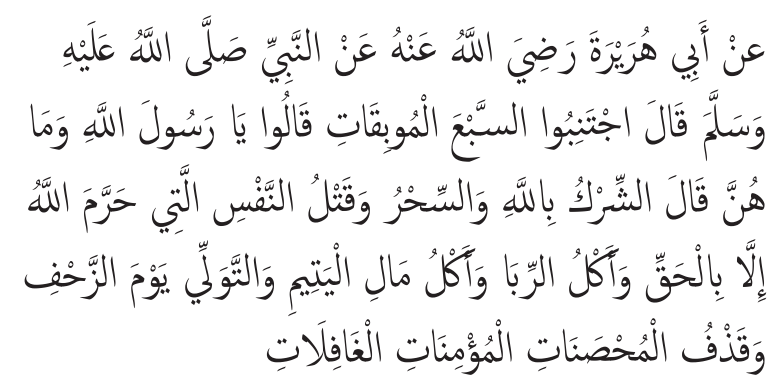

Dari Abu Hurairah radliallahu 'anhu dari Nabi shallallahu 'alaihi wasallam bersabda: "Jauhilah tujuh perkara yang membinasakan". Para sahabat bertanya: "Wahai Rasulullah, apakah itu? Beliau bersabda: "Syirik kepada Allah, sihir, membunuh jiwa yang diharamkan oleh Allah kecuali dengan haq, memakan riba, makan harta anak yatim, kabur dari medan peperangan dan menuduh seorang wanita mu'min yang suci berbuat zina" (H.R. Bukhari, No. 6351).

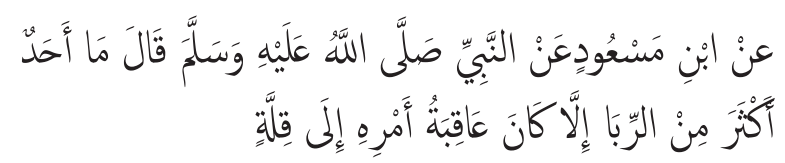

Dari Ibnu Mas'ud dari Nabi shallallahu 'alaihi wasallam, beliau bersabda: "Tidaklah seseorang yang memperbanyak riba, melainkan akhir perkaranya akan merugi" (H.R. Ibnu Majah, No 2270).

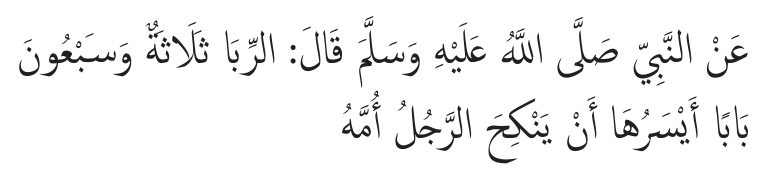

Al- Hakim meriwayatkan dari Ibnu Mas'ud bahwa Nabi saw. bersabda, "Riba itu mempunyai 73 pintu (tingkatan); yang paling rendah (dosanya) sama dengan seseorang yang melakukan zina dengan ibunya." (H.R. Ibnu Majah).

\section{Tafsir Al-Quran Tentang Riba}

Tahap Pertama Tafsir Q.S. Ar-Ruum: 39

Tafsir Ibnu Katsir

Kemudian Allah swt. berfirman yaitu, barang siapa yang memberikan sesuatu guna mengharapkan balasan manusia yang lebih banyak kepadanya dari apa yang diberikan, maka perilaku ini tidak akan mendapatkan pahala di sisi Allah. Demikian yang ditafsirkan oleh Ibnu 'Abbas, Mujahid, adh-Dhahhak, Qatadah, 'Ikrimah, Muhammad bin Ka'ab dan asySya'bi. “Sikap seperti ini dibolehkan, sekalipun tidak memiliki pahala. Akan tetapi, Rasulullah saw melarangnya secara khusus." Itulah yang dikatakan oleh Adh-Dhahhak dan dia berdalil dengan firman Allah swt "Dan janganlah kamu memberi (dengan maksud) memperoleh (balasan) yang lebih banyak" (Q.S. Al-Muddatstsir: 6). Yaitu janganlah engkau memberikan sesuatu karena menghendaki sesuatu yang lebih besar dari pemberianmu itu. Dan Ibnu 'Abbas berkata: "Riba itu ada dua; yang tidak sah yaitu riba buyu' / jual beli dan riba yang tidak mengapa, yaitu hadiah yang diberikan seseorang karena berharap kelebihannya dan pelipatannya. Kemudian 


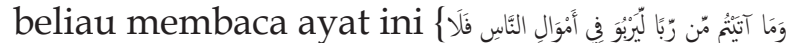
" Dan sesuatu riba (tambahan) yang kamu berikan agar dia menambah pada harta manusia, maka riba itu tidak menambah pada sisi Allah," sedangkan pahala di sisi Allah ada pada zakat (Alu Syaikh, 2008: 225-227).

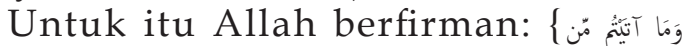

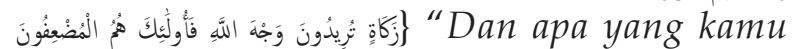
berikan berupa zakat yang kamu maksudkan untuk mencari keridhaan Allah, maka (yang berbuat demikian) itulah orang-orang yang melipatgandakan (pahalanya), "yaitu orang-orang yang dilipatgandakan pahala dan ganjarannya. Di dalam hadits shahih dinyatakan:

"Tidaklah seseorang bershadaqah dengan sepotong kurma yang dikeluarkan dari usahanya yang halal, kecuali Allah Yang Maha Pemurah akan mengambilnya dengan tangan kanan-Nya, lalu dipeliharanya untuk si pemberi shadaqah, sebagaimana salah seorang kalian memelihara anak kuda atau anak unta, hingga kurma itu menjadi lebih besar dari pada bukit Uhud (H.R. Bukhari) (Alu Syaikh, 2008: 225-227).

\section{Tafsir Al Maraghi}

Sebagaimana tafsir Ibnu Katsir, dalam tafsir Al-Maraghi telah diriwayatkan suatu atsar yang bersumber dari Ibnu Abbas ra bahwa ia telah mengatakan, riba itu ada dua macam, yaitu riba yang tidak dibenarkan, ia adalah riba jual beli. Dan lainnya adalah riba yang tidak mengapa jika dilakukan, yaitu pemberian yang diberikan oleh seseorang kepada orang lain dengan maksud supaya ia mendapatkan balasan yang lebih banyak, dan berlipatganda dari apa yang telah diberikannya itu. Selanjutnya Ibnu Abbas membaca ayat ini. Ikrimah dan Ad- Dhahak (dua orang tabi'in) telah mengatakan pula, bahwa riba ada dua macam, yaitu riba yang dihalalkan dan riba yang diharamkan. Adapun riba yang dihalalkan ialah seseorang yang memberikan pemberian kepada orang lain dengan maksud supaya ia mendapatkan balasan yang lebih banyak dari apa yang diberikannya itu. Maka jenis riba ini tidak ada manfaat (pahala) baginya dan tidak pula mudharat (dosa) baginya (AlMaraghi, 1989: 93-98).

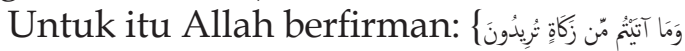
barang siapa yang bersedekah dengan maksud untuk mendapatkan pahala dari sisi Allah, maka ia termasuk orangorang yang pahala dan balasannya akan dilipatgandakan di sisi-Nya. Sebagaimana firman Allah swt dalam ayat lainnya yang berbunyi:

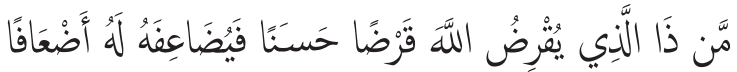

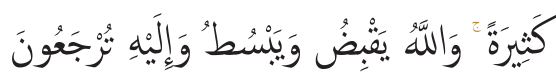

"Siapakah yang memberi pinjaman kepada Allah, pinjaman yang baik (menafkahkan hartanya di jalan Allah), maka Allah akan melipatgandakan pembayaran (pahala) kepadanya dengan lipat ganda yang banyak." (Q.S. Al Baqarah: 245).

\section{Tahap Kedua Tafsir Q.S. An- Nisa: 160-161}

Tafsir Ibnu Katsir

Allah swt mengabarkan bahwa dengan sebab kezhaliman orang Yahudi yang melakukan dosa- dosa besar, maka Allah swt haramkan kepada mereka hal- hal baik yang dahulunya dihalalkan. Pengharaman ini ada yang bersifat qadari (menurut ketentuan sunnatullah) dan ada yang bersifat syar'i (menurut ketentuan syari'at). Dalam arti, bahwa Allah swt mengharamkan sesuatu yang dahulunya halal bagi mereka di dalam Taurat. Sebagaimana firman Allah swt dalam surat al-An'aam:

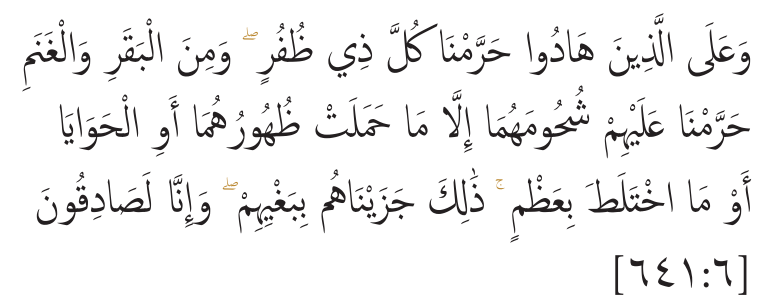

"Dan kepada orang-orang Yahudi, Kami haramkan segala binatang yang berkuku dan dari sapi dan domba, Kami haramkan atas mereka lemak dari kedua binatang itu, selain lemak yang melekat di punggung keduanya atau yang di perut besar dan usus atau yang bercampur dengan tulang. Demikianlah Kami hukum mereka disebabkan kedurhakaan mereka; dan sesungguhnya Kami adalah Maha Benar" (Q.S. Al- An'aam: 146).

Maksudnya yaitu, sesungguhnya sebab Kami mengharamkan hal itu kepada mereka ialah, karena mereka berhak menerimanya disebabkan kedurhakaan mereka, perbuatan mereka yang melampaui batas dan penentangan 
mereka terhadap para Rasul. Maksudnya ialah, bahwa mereka menghalangi manusia dan diri mereka sendiri untuk mengikuti kebenaran. Hal ini merupakan ciri yang menjadi sifat mereka sejak masa lalu hingga masa kini. Untuk itu mereka menjadi musuh- musuh para Rasul, membunuh banyak Nabi, serta mendustakan 'Isa as dan Muhammad saw.

Firman- Nya: \{ \{ disebabkan mereka memakan riba, padahal sesungguhnya mereka telah dilarang daripadanya". Yaitu, sesungguhnya Allah telah melarang riba kepada mereka, akan tetapi mereka justru memakan, mengambil, dan menghiasinya dengan berbagai pikatan dan berbagai bentuk syubhat, serta memakan harta orang lain secara

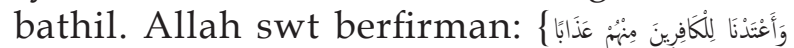
"Kami telah menyediakan untuk orang-orang kafir di antara mereka itu siksa yang pedih." (Alu Syaikh, 2008: 581-582).

\section{Tafsir Al- Maraghi}

Allah swt berfirman

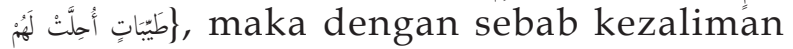
orang- orang Yahudi, akibatnya diharamkan atas mereka beberapa jenis makanan yang baik, yang sebelumnya dihalalkan, sebagai hukuman dan pengajaran atas perbuatan mereka. Diharapkan, dengan demikian mereka mau menghentikan kezalimannya.

Jadi tiap mereka melakukan suatu maksiat, maka diharamkan sejenis makanan yang baik atas mereka. Namun demikian, mereka mengada- ada atas Nama Allah. Mereka katakan, "Kami bukan orang pertama yang dilarang memakan makanan yang baik itu, karena makanan- makanan itu juga sudah diharamkan atas Nuh dan Ibrahim".

Pengajuan mereka seperti itu dinyatakan dusta oleh Allah di berbagai tempat dalam kitab-Nya, seperti firman-Nya:

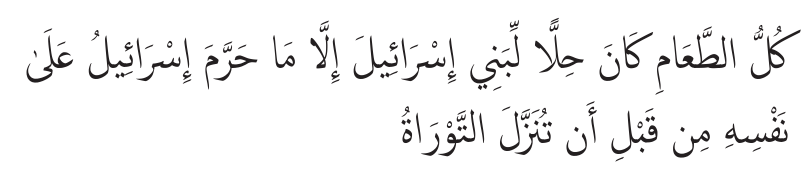

"Semua makanan adalah halal bagi Bani Israil melainkan makanan yang diharamkan oleh Israil (Ya'qub) untuk dirinya sendiri sebelum Taurat diturunkan" (Q.S. Ali Imran: 93).

Adapun makanan- makanan baik yang diharamkan atas orang- orang Yahudi, ialah makanan- makanan yang diterangkan dalam firman Allah Ta'ala:

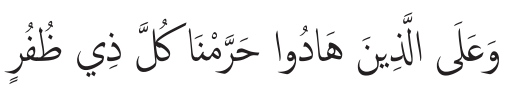

"Dan kepada orang-orang Yahudi, Kami haramkan segala binatang yang berkuku." (AlAn'aam: 146).

Di sini, Allah tidak merinci binatang apa saja, karena tujuan diceritakannya hal tersebut supaya dimengerti, bahwa itu adalah hukuman, tidak bermaksud menerangkan rincian makanan yang diharamkan itu sendiri.

Jadi sama halnya ketika Allah tidak merincikan kezaliman apa saja yang menyebabkan mereka dihukum. Maksudnya, supaya orang tahu, bahwa macam kezaliman apapun bisa saja menjadi sebab turunnya hukuman di dunia, sebelum hukuman akhirat kelak.

Sedangkan hukuman yang dimaksud, bisa jadi berupa hukuman duniawi, seperti beban- beban berat pada saat turunnya syari'at, balasan sebagaimana yang sudah tercantum dalam kitab- kitab atas beberapa jenis dosa, seperti had dan $t a^{\prime} z i r$, dan bisa juga berupa bencana, akibat melanggar Sunnahsunnah yang telah digariskan Allah dalam undang- undang sosial, seperti kezaliman yang bisa menyebabkan lemahnya umat dan kemunduran, kemudian dijajah bangsa lain. Atau, bisa juga berupa hukuman ukhrawi, yaitu hukuman yang telah ditegaskan Allah dalam kitab-Nya yang mulia, berupa siksaan dalam neraka.

Sesudah itu, yakni sesudah Allah menyebutkan kezaliman orang- orang Yahudi secara ijmal, maka diterangkan secara tafsil (terinci), agar lebih mantap dalam hati dan lebih mengena sebagai suatu nasehat:

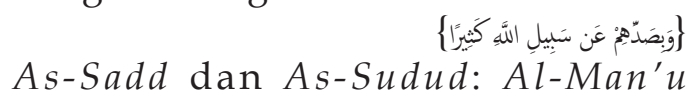
(mencegah, menghalangi). Ini bisa berarti, mereka mencegah diri sendiri dari jalan Allah, yaitu ketika mereka tidak mematuhi perintah Nabi Musa as. dan sering menentangnya. Bisa juga berarti mereka menghalangi orang lain dari jalan Allah dengan memberi contoh yang buruk, atau dengan menyuruh melakukan kemungkaran dan melarang kebajikan. 


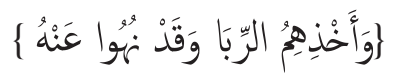

Pengharaman makanan tersebut di atas juga disebabkan mereka memakan riba, padahal mereka telah dilarang memakannya lewat mulut para nabi mereka. Sedangkan Taurat yang ada pada mereka, kini hanya menyatakan pengharaman riba yang diambil dari semua bangsa Yahudi sendiri, dan dari sesama saudara mereka, selain orang asing. Dalam Kitab Keluaran, 22: 25 ada disebutkan: "Jikalau kamu memberi pinjaman uang kepada umatku, yaitu kepada orang miskin di antara kamu, maka jangan kamu menjadi baginya seperti penagih hutang yang keras, dan jangan ambil bunga dari padanya."

Begitu pula dalam Kitab Ulangan, 23: 19-20:

"Maka tidak boleh kamu mengambil bunga daripada saudaramu, baik bunga uang, baik bunga makanan, baik bunga barang sesuatu yang dapat makan bunga. Maka daripada orang lain atau bangsa lain, boleh kamu mengambil bunga, tetapi daripada saudaramu, tak boleh kamu mengambil dia..."

Di atas, adalah kata- kata Taurat yang ditulis sesudah peristiwa penawanan besarbesaran umat Yahudi, yang dengan banyak kesaksian, nyata telah dirubah. Adapun teks yang ditulis sendiri oleh Musa sudah hilang. Hal ini, baik umat Yahudi maupun Nashrani, sama- sama mengakuinya. Sebagian nabi mereka ada yang melarang riba sama sekali, tanpa terkecuali, baik terhadap sesama bangsa Israil ataupun bukan. Seperti kata Nabi Daud dalam Mazmur, 15: 5:

"Maka tiada ia menjalankan uangnya dengan makan bunga dan tiada ia makan suap akan melawan orang tiada bersalah".

Dan kata Sulaiman dalam senandungnya:

"Orang yang memperbanyak hartanya dengan mengambil bunga dan menumpuk-numpuk keuntungan, takkan mengasihani orang-orang fakir dengan tumpukan hartanya itu".

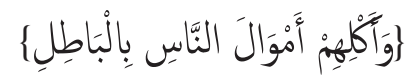

Dan pengharaman makanan tersebut di atas juga dikarenakan mereka memakan harta orang lain secara bathil, yakni dengan menyuap kepada penguasa dan dengan cara khianat, atau cara- cara lain untuk mengambil harta tanpa imbalan yang berarti.

Yang senada dengan ayat ini adalah Firman Allah Ta'ala:

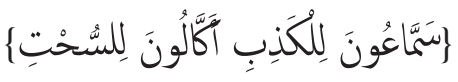

"Mereka itu adalah orang- orang yang suka mendengar berita bohong, banyak memakan harta haram..." (Q.S. Al-Maidah: 42).

As-Suht, ialah kasab dengan cara yang haram. Orang- orang Yahudi itu menjual kitabkitab yang mereka tulis dengan tangan mereka sendiri, dengan mengatakan bahwa kitab- kitab itu dari sisi Allah.

Demikianlah, setelah Allah menyebutkan beberapa jenis dosa dan kejahatan yang mereka lakukan, kemudian diterangkanlah balasan mereka kelak di akhirat atas dosa-dosa tersebut, dengan firman-Nya:

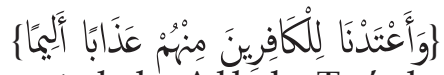

Kemudian, setelah Alláh Ta'ala menerangkan tingkah laku yang buruk dari umat Yahudi, kekafiran dan kemaksiatan yang mereka lakukan, yang dalam hal ini Allah menyebut mereka secara mutlak sehingga bisa membuat salah paham, bahwa yang dimaksud adalah orang Yahudi siapa saja, termasuk yang baik- baik; maka terdapatlah sesudah itu kata "istidrak" (penghubung; tetapi) dengan keterangan tentang orangorang baik di kalangan umat tersebut yang tidak membiarkan dirinya bertaklid buta, bahkan digunakannya cahaya akal mereka (Al-Maraghi, 1987: 30-35).

\section{Tafsir Ruhul Bayan}

Fabizhulmim minal laadzina hadu (maka disebabkan oleh kezaliman orang- orang Yahudi) yakni disebabkan oleh kezaliman yang besar, yang keluar dari batas- batas keserupaan dan bentuk yang keluar dari orang Yahudi.

Harramna alaihim thayyibatin uhillat lahum (Kami haramkan atas mereka yang baik- baik yang telah dihalalkan kepada mereka) dan kepada orang sebelum mereka, bukan karena sesuatu yang selainnya, sebagaimana mereka sangka. Ketika mereka melakukan kemaksiatan dari berbagai kemaksiatan yang mereka lakukan, Allah mengharamkan kepada mereka 
suatu jenis dari makanan yang baik- baik yang sebelumnya dihalalkan kepada mereka dan kepada orang- orang yang hidup sebelum mereka, sebagai hukuman bagi mereka, (yang diharamkan) seperti daging unta, susu dan lemaknya.

Dalam at-Ta'wilatun Najmiyyah dikemukakan beberapa maksud: Allah berfirman kepada mereka: "Kami haramkan kepada mereka yang baik- baik." Dan Dia berfirman kepada kita (umat Nabi Muhammad saw): "Dan Allah menghalalkan bagi kalian yang baik- baik." Dan Dia berfirman: "Makanlah dari sebagian yang telah Allah rizkikan kepada kalian yang halal lagi baik."

Allah tidak mengharamkan suatu makanan pun kepada kita karena dosa yang kita lakukan. Kita pun selamat dari ayat yang mengharamkan yang baik- baik. Maka kita mengharapkan keselamatan dari azab yang pedih di hari akhirat, karena dalam penyebutannya pun disatukan dalam ayat ini.

Wa bishaddihim 'an sabilillahi (dan karena mereka berpaling dari jalan Allah) yakni disebabkan mereka menolak dinullah (Islam), sedangkan mereka merupakan manusia. Katsira (yang banyak) atau mereka banyak berpaling.

Wa akhdzihimur riba wa qad nuhu anhu (dank arena mereka mengambil riba, padahal mereka telah dilarang darinya) karena riba itu diharamkan kepada mereka sebagaimana diharamkan kepada kita. Penggalan ini menunjukkan bahwa larangan itu menunjukkan kepada haramnya perkara yang dilarang.

Wa aklihim amwalan nasi bil bathili (dan karena mereka memakan harta manusia dengan bathil) dengan cara suap dan cara- cara lainnya yang diharamkan. Wa a'tadnaa (dan telah Kami sediakan) yakni Kami telah menciptakan dan menyediakan. Lil kafirina minhum (untuk orang-orang yang kafir di antara mereka) yakni untuk orang yang terus menerus berada dalam kekafiran, bukan untuk orang yang bertaubat dan beriman di antara mereka.

Adzaban 'alima (azab yang pedih) dan menyakitkan, yang rasa sakitnya menembus sampai ke hati mereka. Mereka akan merasakannya di akhirat sebagaimana mereka pun merasakan hukuman haram di dunia (AlBuruswi, 1997: 45-48).
Tahap Ketiga Tafsir Q.S. Ali Imron: 130 Tafsir Ibnu Katsir

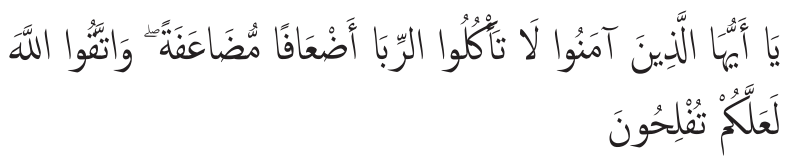

"Hai orang- orang yang beriman, janganlah kamu memakan riba dengan berlipat ganda dan bertakwalah kamu kepada Allah supaya kamu mendapat keberuntungan. (Q.S. Ali Imron: 130).

Melalui firman-Nya di atas, Allah melarang hamba-hamba-Nya yang beriman melakukan riba dan memakannya dengan berlipat ganda. Sebagaimana pada masa Jahiliyyah dulu mereka mengatakan: "Jika hutang sudah jatuh tempo, maka ada dua kemungkinan; dibayar atau dibungakan. Jika dibayar, maka selesai sudah urusan. Dan jika tidak dibayar, maka ditetapkan tambahan untuk jangka waktu tertentu dan kemudian ditambahkan pada pinjaman pokok." Demikian seterusnya pada setiap tahunnya. Mungkin jumlah sedikit bisa berlipatganda menjadi banyak.

Dan Allah swt memerintahkan hambahamba-Nya untuk bertakwa agar mereka beruntung di dunia dan di akhirat. Selanjutnya Allah mengancam dan memperingatkan dari api Neraka, "Dan peliharalah dirimu dari api Neraka, yang disediakan untuk orang-orang yang kafir. Da taatilah Allah dan Rasul, supaya kamu diberi rahmat." (Alu Syaikh, 2008: 173-175).

\section{Tafsir Al Maraghi}

Dhi'fa'sy-Syai': dua kali lipat. Lipatan satu adalah satu sebab, bila ditambahkan padanya maka menjadi dua. Bila engkau melipatkan sesuatu, berarti engkau memberikan padanya satu kali, baik sekali atau lebih banyak lagi. Dan pengertian berlipat ganda ini ada kalanya dalam pertambahannya saja, seperti riba, atau bisa juga dalam pokok modalnya saja, seperti yang lazim terjadi sekarang. Yaitu seseorang meminjam seratus rupiah dan harus mengembalikan tiga ratus rupiah.

Wa't Taqu'l-Laha: jadikanlah taqwa itu sebagai tameng bagi diri kamu dari siksaanNya. U'iddat: yang telah disediakan.

Al-Musara'ah ila 'l-Maghfirah dan AlJannatul'l-Mubadirah: menuju kepada penyebab 
yang bisa mengantarkan kepada ampunan dan surga, yaitu amal- amal saleh, seperti melakukan sedekah, amal- amal kebajikan, taubat dari dosa- dosa, seperti riba dan lain sebagainya.

Dalam ayat yang lalu, Allah melarang kaum Mu' minin mengambil teman khusus dari kalangan Yahudi dan sebangsanya, yaitu orangorang musyrik dengan syarat-syarat yang telah disebutkan tadi, karena hal ini merupakan sumber kecelakaan dan bahaya. Lalu, Allah menjelaskan kepada kaum Mu'minin bahwa tipu muslihat mereka (Yahudi dan musyrikin) tidak akan membahayakan kaum Mu'minin, sedang mereka berpegang pada takwa kepada Allah swt dan taat kepada Rasul-Nya.

Kemudian, di sini Allah swt melarang melakukan perbuatan paling jelek yang biasa dilakukan kaum Yahudi dan pengikut mereka dari kalangan musyrikin, yakni perbuatan riba. Di samping itu, Allah menjelaskan bahwa laba yang diduga dari hasil riba itu bukan merupakan sebab kebahagiaan, tetapi kebahagiaan yang sejati bersumber dari takwa kepada Allah dan melaksanakan perintahperintah-Nya. Dalam hal ini, menyangkut imbauan untuk menginfakkan harta ke jalan Allah, seperti membela Agama-Nya, sekaligus mengusir sifat bakhil, kikir, dan mengejar harta untuk mengumpulkannya dengan segala cara yang bisa dilakukan. Sedang sarana atau cara yang paling jelek ialah melakukan riba dengan berlipat ganda.

Janganlah kalian memakan riba yang berlipat ganda hanya dengan menangguhkan pembayaran modal, sehingga modal menjadi berlipat, seperti yang biasa kalian lakukan pada zaman Jahiliyyah. Kini, Islam melarang kalian berbuat demikian, karena hal itu merupakan cara keras dan pemerasan terhadap orang yang sedang membutuhkan pertolongan.

Imam Ibnu Jarir mengatakan, "Janganlah kalian memakan riba berlipat ganda dalam Islam, sesudah Allah memberikan petunjuk kepada kalian, seperti yang kalian lakukan pada zaman Jahiliyyah. Dalam masa Jahiliyyah, seseorang melakukan riba berlipat ganda ini dengan cara memberikan hutang kepada orang lain dengan masa pembayaran yang disebutkan waktunya. Bila waktu pembayaran telah tiba, yang berpiutang meminta kepada yang berutang, dan biasanya yang berutang akan mengatakan, 'Tangguhkanlah pembayaran uangmu, nanti akan aku tambah lagi,' keduanya menyetujui hal itu. Itulah yang dinamakan riba berlipat ganda. Kemudian, Allah swt mencegah mereka melakukannya dalam agama Islam.

Imam Ar-Razi mengatakan, "Pada masa Jahiliyah, bila seseorang berutang kepada seseorang sebanyak seratus dirham, jika telah tiba waktu pembayarannya, ternyata orang yang berutang belum bisa membayar utangnya, ia akan mengatakan, "Tambahilah waktu pembayarannya, biar nanti aku tambah jumlah pembayarannya." Dan ini, terkadang mencapai jumlah dua ratus dirham. Setelah tiba waktu yang dijanjikan, terulang lagi hal yang serupa, dan hal itu terjadi beberapa kali. Sehingga dari seratus dirham, ia dapat mengambil berlipat ganda dari modalnya. Demikianlah yang dimaksud dengan firmanNya: Adh'afan Mudha'afah.

Pada masa sekarang, Riba Jahiliyah disebut juga riba fahisy (keterlaluan labanya) atau riba yang labanya berlipat ganda dari modalnya. Allah telah mengharamkan riba dan melaknat pemakannya, wakilnya, penulisnya, dan saksinya. Kemudian memberikan peringatan kepada orang yang tidak mau meninggalkannya, bahwa mereka diperangi oleh Allah dan Rasul-Nya. Ancaman seperti ini belum pernah ada dalam dosa besar, oleh karenanya riba dikategorikan dosa besar yang terbesar.

Dalam hadits telah disebutkan bahwa orang yang mengambil riba itu tidak diterima sedekahnya, jihadnya, hajinya, dan shalatnya (Al Maraghi, 1986: 112). Kemudian Allah mengukuhkan larangan-Nya:

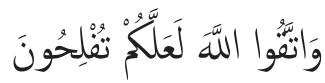

Bertakwalah kalian kepada Allah dalam hal- hal yang dilarang, diantaranya ialah riba, dan janganlah hati kalian keras berlaku kasar terhadap hamba-hamba-Nya yang membutuhkan dan sengsara, sehingga kalian membebankan utang yang tak kuat mereka tanggung, dan kalian memeras hajat serta kebutuhan mereka. Mereka ditenggelamkan oleh riba, sehingga rumah mereka ludes, dan akhirnya menjadi orang papa yang tidak mempunyai apapun lagi. 
Mudah- mudahan bila kalian mau berlaku baik terhadap mereka, hal itu akan menjadi penyebab kebahagiaan kalian di dunia. Sebab, kasih sayang dan pertolongan yang baik itu akan menumbuhkan kecintaan dalam hati orang yang ditolong, sedang kecintaan itu adalah dasar dari kebahagiaan di dunia dan akhirat. Dan Allah menambahkan larangan-Nya sebagai penguat. Jauhilah oleh kalian menempuh jalan orang- orang yang suka berbuat riba, dan jauhilah praktik suka memakan riba, karena akan menyeret kamu ke Neraka yang telah disediakan oleh Allah untuk orang- orang kafir (Al Maraghi, 1986: 104-114).

Tafsir Ruhul Bayan

(Wahai orangorang yang beriman, janganlah kalian memakan riba). Yang dimaksud dengan makan riba ialah mengambilnya. Mengambil diungkapkan dengan makan karena kebanyakan dan kebiasaan yang sangat lumrah mengambil riba' sangat berkaitan dengan makan, dan makan mengandung makna lebih buruk.

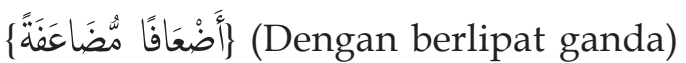
dengan penambahan yang berulang- ulang. Pada zaman jahiliyah, apabila seseorang punya piutang kepada orang lain sebanyak seratus dirham, namun penghutang tidak dapat melunasinya tatkala jatuh tempo, pemilik piutang berkata: “Tambahilah piutangku, nanti kamu saya kasih tempo." Pemilik piutang mungkin dapat meminta tambah seratus dirham lagi. Kemudian tiba masa pembayaran yang kedua dan pemilik piutang melakukan hal serupa hingga terus menerus diundur sehingga uang yang awalnya seratus dirham menjadi berlipat ganda. Adh'afjamak dari kata dha'fun yang dikaitkan dengan riba, yakni: Dengan berlipat ganda. Pelarangan ini bukan untuk mensyaratkan larangan hanya berlaku untuk mudha'afa (berlipat ganda), tidak haram kalau tidak berlipat ganda, akan tetapi kata itu bertujuan mencela tradisi yang biasa mereka lakukan.

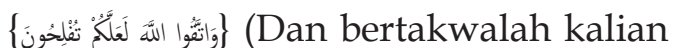
kepada Allah) dari apa- apa yang dilarangNya, terutama riba dan perbuatan riba'. (Supaya kalian mendapat keberuntungan), mendapat kebahagiaan (Al- Buruswi, 1996: 138-139).

Tahap Keempat Tafsir Q.S. Al- Baqarah: 275281

Tafsir Ibnu Katsir

Allah swt mengibaratkan keadaan orang yang memakan riba pada saat bangkit dan keluar dari kubur pada hari kebangkitan. Mereka tidak dapat berdiri dari kuburan mereka pada hari Kiamat kelak kecuali seperti berdirinya orang gila pada saat mengamuk dan kerasukan syaitan. Yaitu mereka berdiri dengan posisi yang tidak sewajarnya.

Ibnu 'Abbas mengatakan: "Pemakan riba akan dibangkitkan pada hari Kiamat kelak dalam keadaan seperti orang gila yang tercekik."

Imam Bukhari meriwayatkan dari Samurah bin Jundub, dalam hadits panjang tentang mimpi: "Maka tibalah kami di sebuah sungai, aku menduga ia mengatakan: 'Sungai itu merah semerah darah.' Ternyata di sungai tersebut terdapat seseorang yang sedang berenang, dan di pinggirnya terdapat seseorang yang telah mengumpulkan batu yang sangat banyak di sampingnya. Orang itu pun berenang mendatangi orang yang mengumpulkan batu itu. Kemudian orang yang berenang itu membuka mulutnya, lalu ia menyuapinya dengan batu." (H.R. Al-Bukhari). Dan dalam menafsirkan peristiwa tersebut dikatakan bahwa ia itulah pemakan riba (Alu Syaikh, 2008: 694-712).

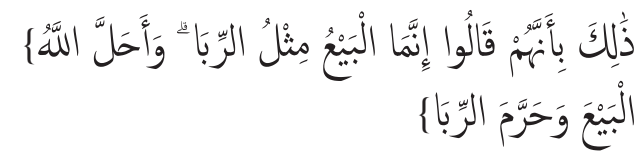

Maksudnya, mereka membolehkan riba dengan maksud menentang hukum- hukum Allah yang terdapat dalam syariat-Nya. Bukan karena mereka mengqiyaskan riba dengan jual beli, sebab orang- orang musyrik tidak pernah mengakui penetapan jual beli yang telah ditetapkan Allah di dalam AlQuran. Seandainya hal itu termasuk masalah qiyas, niscaya mereka akan mengatakan: "Sesungguhnya riba itu sama dengan jual beli." Tetapi dalam hal ini mereka mengatakan, "Sesungguhnya jual beli itu sama dengan riba." Artinya, keduanya serupa, lalu mengapa Dia 
mengharamkan yang ini dan menghalalkan yang itu?

Yang demikian itu merupakan penentangan mereka terhadap syari' at. Artinya, yang ini sama dengan ini, dan Dia sendiri telah menghalalkan ini dan mengharamkan yang ini. Sungguh Allah Maha Mengetahui segala hakikat dan kemashlahatan persoalan. Apa yang bermanfaat bagi hamba-hamba-Nya, maka Dia akan membolehkannya bagi mereka, dan apa yang membahayakan bagi mereka, maka Dia akan melarangnya bagi mereka. Kasih sayang Allah kepada para hamba-Nya lebih besar daripada sayangnya seorang ibu kepada anak bayinya.

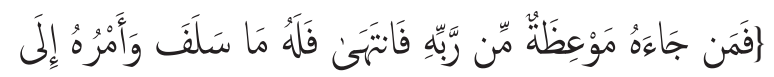

Maksudnya, barang siapa yang telah sampai kepadanya larangan memakan riba, lalu ia mengakhirinya ketika syariat sampai kepadanya, maka baginya hasil mu'ammalah terdahulu. Yang demikian itu didasarkan pada firman-Nya: "Allah memaafkan apa yang telah berlalu." (Q.S. Al-Maa-idah: 95).

Rasulullah saw tidak menyuruh mereka mengembalikan keuntungan yang mereka peroleh pada masa Jahiliyah, tetapi Allah swt telah memaafkan mereka atas apa yang telah berlalu. Sebagaimana firman Allah: "Maka baginya apa yang telah diambilnya dahulu (sebelum datangnya larangan), dan urusannya terserah kepada Allah."

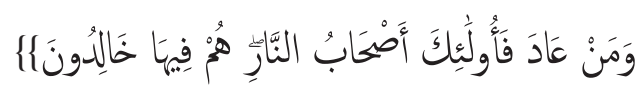

Maksudnya, kembali mengambil riba, dan ia mengerjakannya setelah sampai kepadanya larangan tersebut, maka wajib baginya hukuman dan penegasan hujjah atasnya. Oleh karena itu Allah swt berfirman: "Maka orang itu adalah penghuni-penghuni Neraka, mereka kekal di dalamnya."

Rasulullah saw bersabda, "Barangsiapa yang tidak meninggalkan mukhabarah ${ }^{4}$, maka

\footnotetext{
${ }^{4}$ Mukhabarah adalah menyewakan tanah dengan imbalan sebagian hasil buminya. Sedangkan Muzabanah ialah menjual kurma basah yang masih ada di pohonnya dengan kurma kering yang sudah ada di atas tanah. Dan Muhaqalah ialah membeli biji yang masih melekat
}

maklumkanlah perang kepadanya dengan Allah dan Rasul-Nya. Hadits ini diriwayatkan oleh Hakim dalam Mustadrak-nya ${ }^{5}$ (Alu Syaikh, 2008: 694-712).

Imam Ahmad meriwayatkan dari Abu Hurairah bahwa Rasulullah saw bersabda (432), "Akan datang suatu masa di mana manusia banyak memakan riba." Abu Hurairah berkata, "Rasulullah ditanya, 'Apakah seluruh manusia?' Beliau menjawab, 'Orang yang tidak memakannya pun akan terkena debunya." (H.R. Abu Daud, Nasa'I dan Ibnu Majah).

Dan Allah Ta'ala memberitahukan bahwa Dia menghapuskan dan melenyapkan riba dari pelakunya, baik secara total maupun Dia menghilangkan keberkahan hartanya sehingga tidak bermanfaat, dan pada hari kiamat Dia akan menyiksanya. Sebagaimana Allah swt berfirman, "Dan sesuatu riba yang kamu berikan agar dia menambah pada harta manusia, maka riba itu tidak menambah pada sisi Allah." (Q.S. Ar-Ruum: 39).

Ahmad meriwayatkan dari Ibnu Mas'ud dari Nabi saw, dia bersabda (435), "Sesungguhnya meskipun riba itu pada mulanya banyak, namun akhirnya ia menjadi sedikit." Inilah dari segi muammalah, dan itu bertentangan dari tujuan mengambil riba (supaya banyak). Firman Allah, "Dan menyuburkan sedekah." Yurbi berasal dari raba asy-sya'i, yarbuu, arbaahu, yarbiihi yang berarti mengembangbiakkan dan menjadikannya banyak. Ada juga yang membacanya dengan yurabbi, jika demikian ia berasal dari tarbiyyah.

Dan Allah tidak menyukai orang yang hatinya senantiasa ingkar, perkataan dan perbuatannya berdosa. Suatu keharusan adanya keselarasan dengan sifat ini dalam mengakhiri ayat ini. Sifat itu ialah bahwa seorang pengembang tidak puas dengan harta halal yang telah diberikan Allah kepadanya. Lalu, ia berusaha untuk memakan harta orang lain dengan cara yang bathil dan melalui aneka usaha yang jahat. Dengan demikian, berarti dia senantiasa mengingkari nikmat Allah yang

pada bulirnya di lading dengan biji yang sudah ada di atas tanah. Semua nya haram (tergolong riba) sebab belum diketahui kesamaan dua barang tersebut sebelum keduanya kering betul.

5 Menurutnya hadits ini shahih menurut kriteria Muslim, meskipun Muslim sendiri tidak meriwayatkannya. 
ada padanya, zalim, dan berbuat dosa lantaran memakan harta orang lain dengan bathil.

Kemudian, Allah berfirman seraya memuji orang- orang yang beriman kepada Tuhan mereka, menaati perintah-Nya, bersyukur kepada-Nya dan berbuat baik kepada makhluk-Nya. Semua itu diwujudkan dalam amal saleh, pelaksanaan shalat dan penunaian zakat. Sesungguhnya bagi mereka tidak ada kekhawatiran dan tidak pula bersedih hati.

Allah menyuruh hamba- hamba-Nya yang beriman agar bertakwa kepada-Nya. Allah pun melarang mereka melakukan sesuatu yang mendekatkan mereka kepada kemurkaan-Nya dan menjauhkan mereka dari keridhaan-Nya. Dia berfirman, "Hai orang- orang yang beriman, bertakwalah kepada Allah," takutlah kepadaNya dan hati- hatilah dalam berbuat karena Dia mengawasimu," serta tinggalkanlah sisa riba", yakni tinggalkanlah hartamu yang merupakan kelebihan dari pokok yang harus dibayar oleh orang lain, setelah menerima peringatan ini, "jika kamu adalah orang- orang yang beriman" kepada apa yang disyariatkan Allah, yaitu penghalalan jual beli, pengharaman riba, dan syariat lainnya (Alu Syaikh, 2008: 694-712).

Diceritakan, "Zaid bin Aslam dan yang lainnya menuturkan bahwa redaksi ayat itu diturunkan berkaitan dengan bani Amr bin Umeir dari Tsaqif dan berkaitan dengan bani Mughirah dari Bani Makhzum. Telah terjadi riba di antara mereka pada masa jahiliyyah. Setelah Islam datang dan mereka memeluknya, Tsaqif minta hartanya dari Bani Mughirah. Kemudian mereka bermusyawarah. Bani Mughirah berkata, "Kami tidak akan melakukan riba dalam Islam dan akan menggantinya dengan usaha yang islami." Kemudian Utab Ibnu Asid, pemimpin Mekkah, melaporkan hal itu kepada Nabi saw dalam sepucuk surat. Maka diturunkanlah ayat di atas. Lalu, Rasulullah saw membalas Utab dengan surat yang berbunyi, "Hai orang- orang yang beriman, bertakwalah kepada Allah dan tinggalkanlah sisa riba, apabila kamu adalah orang- orang yang beriman. Apabila kamu tidak melaksanakan, maka ketahuilah bahwa Allah dan Rasul-Nya akan memerangimu." Maka mereka berkata, "Kami bertobat kepada Allah dan kami akan meninggalkan sisa riba.
Maka mereka semua meninggalkannya." Maka hindarkanlah dirimu dari keterlibatan dengan jual beli riba, karena Allah telah meluaskan perkara halal dan menjadikannya baik. Maka jangan sekali- kali kamu terperosok ke dalam kemaksiatan kepada-Nya."

Allah berfirman, "apabila kamu bertobat, maka bagimu pokok hartamu: kamu tidak menganiaya" dengan mengambil tambahan" dan tidak pula dianiaya" dengan menghanguskan pokok harta. Namun, kamu memperoleh apa yang telah kamu berikan tanpa tambahan atau kekurangan. Firman Allah, "Dan apabila dia dalam kesukaran, maka berilah tangguh sampai dia berkelapangan. Dan menyedekahkan itu lebih baik bagimu, jika kamu mengetahui." Allah swt menyuruh bersabar dalam menghadapi orang yang kesulitan dan tidak dapat membayar. Kemudian Allah menganjurkan untuk menghapuskan saja. Dan Dia pun menjanjikan kepadanya, bila berbuat demikian, kebaikan dan pahala yang banyak. Allah berfirman, "Dan menyedekahkan itu lebih baik bagimu, jika kamu mengetahui." Maksudnya, apabila kamu tidak mengambil pokok pinjaman secara keseluruhan dan membebaskan si peminjam dari kewajibannya membayar utang, maka hal itu lebih baik bagimu. Sebagaimana Rasulullah saw bersabda, "Barangsiapa yang ingin mendapat naungan Allah pada hari yang tiada naungan kecuali naungan-Nya, maka hendaklah dia memberi kemudahan kepada yang kesulitan, atau membebaskannya dari kesulitannya." (H.R. Thabrani).

Al- Bukhari meriwayatkan dari Abu Hurairah ra, dari Nabi saw dia bersabda, "Ada pedagang yang berpiutang kepada manusia. Apabila pedagang ini melihat mereka kesulitan, maka dia berkata kepada para pegawainya, 'Maafkanlah dia, mudah- mudahan Allah pun memaafkan kita.' Maka Allah pun memaafkan si pedagang."

Kemudian Allah Ta'ala berfirman guna menasehati hamba-hamba-Nya, mengingatkan kepada mereka ihwal lenyapnya dunia dan datangnya akhirat, kembalinya manusia kepada Allah, perhitungan Allah terhadap apa yang dilakukan makhluk-Nya, pemberian balasan atas mereka selaras dengan kebaikan atau keburukan yang telah mereka lakukan, dan Dia pun mengingatkan mereka terhadap 
azab-Nya. Allah Ta'ala berfirman, “Dan takutlah kamu terhadap suatu hari di mana kamu dikembalikan kepada Allah. Kemudian setiap diri diberi balasan yang penuh atas apa yang telah dikerjakannya, sedang mereka tidak dianiaya sedikit pun." (Alu Syaikh, 2008: 694-712).

\section{Kondisi Perekonomian Kontemporer Terkait Riba}

Industri asuransi konvensional menerima pembayaran premi dalam sejumlah prosentase tertentu (kecil), maka Penanggung berjanji akan memberikan ganti rugi apabila terjadi risiko kerugian (klaim) yang dijamin polis maksimum sebesar nilai asset yang dipertanggungkan dimana nilainya bisa jauh lebih besar bahkan berkali - kali lipat nilainya dari premi.

Ditinjau dari sisi investasi, dana premi yang terkumpul dari partisipasi nasabah diinvestasikan dalam berbagai jenis investasi yang tidak memenuhi persyaratan Syariah. Contohnya dana diinvestasikan pada interest-bearing bonds dimana interest atau bunga dikategorikan sebagai riba sehingga investasinya menjadi impermissible dan tidak comply terhadap pinsip Syariah.

Selain itu, aplikasi tawarruq munazzham yang dipraktikan oleh bank- bank unit syariah khususnya di Saudi Arabia, menurut AlMajma' Al Fiqhy Al Islami dinyatakan dan diputuskan bahwa produk ini haram hukumnya. Dan disebutkan bahwa hakikat muammalah ini berbeda dengan tawarruq haqiqi yang diperbolehkan oleh para ulama. Sebab hakikat tawarruq munazzham memposisikan pihak pembeli belum menerima barangnya namun ia sudah dapat mewakilkan kepada pihak bank untuk menjualnya kembali. Seperti nasabah menerima uang 1 juta riyal tunai dari bank dan wajib membayar utang 1 juta 200 ribu riyal dengan cara angsuran. Hal ini disamakan dengan pengembalian pinjaman uang yang berlebih sehingga tergolong riba (Tarmizi, 2012).

\section{KESIMPULAN}

Secara umum, riba terdiri atas 2 kelompok bagian yaitu riba berdasarkan transaksi hutang piutang (riba qardh dan riba jahiliyyah) serta riba berdasarkan transaksi jual beli barang ribawi (riba fadhl dan riba nasi'ah). Tahapan larangan riba terdiri atas 4 tahap, yaitu Q.S. Ar-Ruum: 39, Q.S. An-Nisa: 160-161, Q.S. Ali Imran: 130 dan tahap terakhir Q.S. Al-Baqarah: 275-281. Adapun beberapa hadits terkait riba, salah satu nya dari Jabir dia berkata, "Rasulullah shallallahu 'alaihi wasallam melaknat pemakan riba, orang yang menyuruh makan riba, juru tulisnya dan saksi-saksinya." Rasul berkata, "Mereka semua sama." (H.R. Muslim). Dalam kaidah fiqih disebutkan bahwa setiap pinjaman yang memberikan keuntungan bagi pemberi pinjaman adalah riba. Maka tidak ada pembenaran dalam mengambil riba apapun jenisnya.

\section{DAFTAR PUSTAKA}

Al Quran Al Karim.

Hadits Bulugul Maram.

Al- Buruswi, Ismail Haqqi. 1996, Tafsir Ruhul Bayan Jilid 4, Diterjemahkan oleh Syihabuddin, Diedit oleh Dahlan, HMD dan Yuro, Anwar, Bandung: Diponegoro. Cetakan Pertama. Hal. 138-139.

Al- Buruswi, Ismail Haqqi. 1997, Tafsir Ruhul Bayan Jilid 6, Diterjemahkan oleh Syihabuddin, Diedit oleh Dahlan, H M D dan Yuro, Anwar, Bandung: Diponegoro. Cetakan Pertama. Hal. 45-48.

Al- Maraghi, Ahmad Mushthafa. 1986, Tafsir Al Maraghi Jilid 4, Diterjemahkan oleh Abubakar, Bahrun dan Aly, Hery Noer, Diedit oleh Rasyidi, Anwar, Semarang: Toha Putra Semarang, Cetakan Pertama. Hal. 104-114.

Al- Maraghi, Ahmad Mushthafa. 1987, Tafsir Al Maraghi Jilid 6, Diterjemahkan oleh Abubakar B, Aly H N, dan Sitanggal A U, Diedit oleh Rasyid A dan Dasuki H, Semarang: Toha Putra Semarang, Cetakan Pertama. Hal. 30-35.

Al- Maraghi, Ahmad Mushthafa. 1989, Tafsir Al Maraghi Jilid 21, Diterjemahkan oleh Abubakar B, Aly H N, dan Sitanggal A U, Diedit oleh Rasyid A, Semarang: Toha Putra Semarang, Cetakan Pertama. Hal. 93-98.

Alu Syaikh, Dr. 'Abdullah bin Muhammad bin 'Abdurrahman bin Ishaq. 2008, Tafsir Ibnu Katsir Jilid 1, Diterjemahkan oleh Ghoffar, 
M. 'Abdul, Diedit oleh Harun, M. Yusuf et al, Jakarta: Pustaka Imam Asy-Syafi'i, Cetakan Pertama. Hal 694-712.

Alu Syaikh, Dr. 'Abdullah bin Muhammad bin 'Abdurrahman bin Ishaq. 2008, Tafsir Ibnu Katsir Jilid 2, Diterjemahkan oleh Ghoffar, M. 'Abdul, Diedit oleh Harun, M. Yusuf et al, Jakarta: Pustaka Imam Asy-Syafi'i, Cetakan Pertama. Hal 173175 dan 581-582.

Alu Syaikh, Dr. 'Abdullah bin Muhammad bin 'Abdurrahman bin Ishaq. 2008, Tafsir Ibnu Katsir Jilid 7, Diterjemahkan oleh
Ghoffar, M. 'Abdul dan Al- Atsari, Abu Ihsan, Diedit oleh Harun, M. Yusuf et al, Jakarta: Pustaka Imam Asy-Syafi'i, Cetakan Pertama. Hal 225-227.

Antonio, Muhammad Syafi' i. 2001, Bank Syariah dari Teori ke Praktik, Jakarta: Gema Insani Press. Hal 4, 37 dan 41.

Quthb, Sayyid. 2000, Tafsir fi Zhilalil Qur'an di Bawah Naungan Al-Qur'an Jilid 1, Jakarta: Gema Insani Press. Hal. 380.

Tarmizi, Erwandi. 2012, Harta Haram Muammalat Kontemporer, Bogor: Berkat Mulia Insani. Hal. 392-395. 